\title{
Daily Life, Communication and Affections of Siblings and Parents of Military Service Members in Mission
}

\author{
Ana Santos Duarte ${ }^{1}$ (D) https://orcid.org/0000-0002-9198-7810 \\ Rita Francisco 2,3 (D) https://orcid.org/0000-0001-9101-523X \\ Maria Teresa Ribeiro' ${ }^{1}$ (D) https://orcid.org/0000-0002-8314-205X \\ Renato Pessoa dos Santos ${ }^{1,4}$ (D) https://orcid.org/0000-0003-0300-4675
}

\begin{abstract}
The Portuguese military in mission state that parents and siblings are a fundamental support; however, research is very scarce in this area. This study aimed to investigate the impact of a mission on the daily life, communication and emotional responses of 227 relatives of 92 military personnel, 114 siblings $\left(M_{\text {age }}=29.14, S D=9.81\right)$ e 113 parents $\left(M_{\text {age }}=55.06, S D=9.12\right)$. A questionnaire related to the mission was applied, focusing on changes in the daily life, social support, communication and advice to other family members; and the Positive and Negative Affect Schedule since receiving notification. The results revealed that the parents suffered more with the notification and that there were changes in family functioning and in the functional support. Communication with the deployed military service member strengthens family relationships, morale, and well-being. Participants reported emotions of concern and pride, and gave advice based on a positive attitude toward the military and the mission.
\end{abstract}

Keywords: military psychology, emotions, communication, family relations, relatives

\section{Cotidiano, Comunicação e Afetos dos Irmãos e Progenitores dos Militares em Missão}

\begin{abstract}
Resumo: Os militares portugueses em missão costumam mencionar que pais e irmãos são um apoio fundamental, contudo a investigação é muito escassa nesta área. Este estudo teve como objetivo investigar o impacto de uma missão no cotidiano, comunicação e nas respostas emocionais de 227 familiares de 92 militares, 114 irmãos $\left(M_{\text {idade }}=29.14, D P=9.81\right)$ e 113 progenitores $\left(M_{\text {idade }}=55.06\right.$, $D P=9.12$ ). Aplicou-se um questionário relativo à missão, focando alterações do cotidiano, suporte social, comunicação e conselhos a outros familiares; e a Escala de Afetos Positivos e Negativos perante a notificação da mesma. Os resultados revelaram que os progenitores sofreram mais com a notificação e que existiram alterações no funcionamento familiar e no suporte funcional. A comunicação com o militar destacado fortalece as relações familiares, a moral e o bem-estar. Os participantes destacaram as emoções de preocupação e orgulho assim como conselhos pautados por uma atitude positiva face aos militares e à missão.
\end{abstract}

Palavras-chave: psicologia militar, emoções, comunicação, relações familiares, parentes

\section{Rutina, Comunicación y Afectos de los Hermanos y Padres de los Militares en Misión}

\begin{abstract}
Resumen: Los militares portugueses en misión mencionan que los padres y hermanos son un apoyo fundamental, pero la investigación es muy escasa en esta área. Este estudio tuvo como objetivo investigar el impacto de una misión en la vida cotidiana, la comunicación y las respuestas emocionales de 227 familiares de 92 militares, 114 hermanos $\left(M_{\text {edad }}=29.14 S D=9.81\right)$ y 113 padres $\left(M_{\text {edad }}=55.06, S D=9.12\right)$. Se aplicó un cuestionario de misión, centrado en los cambios diarios, el apoyo social, la comunicación y el asesoramiento a otros miembros de la familia; y la Escala de Afectos Positivos y Negativos tras la notificación. Los resultados revelaron que los padres sufrieron más con la notificación y que hubo cambios en el funcionamiento familiar y el apoyo funcional. La comunicación con el militar separado fortalece las relaciones familiares, la moral y el bienestar. Los participantes destacaron emociones de preocupación y orgullo, así como consejos basados en una actitud positiva hacia los militares y la misión.
\end{abstract}

Palabras clave: psicología militar, emociones, comunicación, relaciones familiares, parientes

${ }^{1}$ Universidade de Lisboa, Lisboa, Portugal

${ }^{2}$ Universidade Católica Portuguesa, Lisboa, Portugal

${ }^{3}$ Catolica Research Centre for Psychological, Family and Social Wellbeing, Lisboa, Portugal

${ }^{4}$ Academia Militar, Exército Português, Portugal

Article derived from the master's dissertation of the first author under the supervision of the second and fourth, defended in 2016, for the Integrated Masters' Degree in Psychology, Faculdade de Psicologia da Universidade de Lisboa, Portugal.

Correspondence address: Renato Pessoa dos Santos. Academia Militar. Avenida Conde Castro Guimarães, 2720-113. Amadora, Portugal. E-mail: santos.recp@mail.exercito.pt
Separation due to an international military mission is one of the major factors of stress for military families (Bóia, Marques, Francisco, Ribeiro, \& Santos, 2018). Military parents and siblings experience great anguish (Rodriguez \& Margolin, 2011), but are considered by the military as an important support during the mission (Institute of Medicine (2013). Bunch, Eastman and Moore (2007) report that military parents may even present levels of clinical stress. Other studies reveal that extended families would like to communicate more with 
the deployed military and the military services, but they get information through the military's spouse, who is the one that often maintains contact with the military (Greene, Buckman, Dandeker, \& Greenberg, 2010). Since studies on the experience of military siblings and parents during their participation in international missions are scarce, there is no written information about the changes in their daily lives, about the communication with their military relative and their affections during this period, which is the subject of this study.

In general, each military mission has three phases: the pre-deployment, which begins with the notification until the military departs to the operational theaters (OT); the deployment, period that corresponds to the time that the military is in the OT; and post-deployment, which begins when the service member definitely returns home (Houston, Pfefferbaum, Sherman, Melson, \& Brand, 2013). Several studies have revealed that the resources needed for a good family adaptation during the mission in its different phases are the social support of friends, the functional support of family members and the communication between family and the military (Barbudo, Francisco, \& Santos, 2014; Bóia et al., 2018; Manigart, Lecoq, \& Bue, 2015; Martins, Santos, \& Francisco, 2014). However, it is also essential to have individual coping resources and strategies, such as having a positive attitude towards the situation, learning from previous identical experiences, and the control of negative emotions (Bóia et al., 2018).

Regarding the deployment, families establish communications with the military and with each other. Some studies suggest that the use of communication during the mission, especially online communication, is a positive influence and a support for military family members (Carter \& Renshaw, 2016; Rea, Behnke, Huff, \& Allen, 2015), thus becoming a key component for establishing and maintaining close relationships (Solomon $\&$ Vangelisti, 2014). The extended families report that they would like to communicate more with the deployed service member and military services to get more information about, for example, his or her location, performance and the return schedule (Basinger \& Knobloch, 2017). Family members are sometimes "reprimanded" by the military services because of the overload on communication lines, given the frequency of requests for information about the service members. When there is a nonmilitary spouse, the rest of the family (e.g., military's parents and siblings) has little contact with the military during the mission, receiving information only from the spouse who often maintains contact with the deployed element (Greene et al., 2010). In situations where communication is minimal, families try to obtain information through the media, and this solution may trigger some anxiety (Matthews-Juarez, Juarez, \& Faulkner, 2013). Therefore, Whealin and Pivar (2019) report that families should gather information from reliable resources. During the deployment also arises the challenge of the amount and speed of information provided by the use of phone and email. Over long distances and without a face-to-face contact, communications are vulnerable to distortion or equivocal perception. Thus, the most sensitive issues, which may be more problematic, are kept for the end of the mission (Pincus, House, Christenson, \& Alder, 2001). Communication (interactive or delayed) is the strategy most mentioned by couples as a means of reducing the consequences of physical separation during deployment (Carter et al., 2011; Rea et al., 2015). A study with Portuguese military mentions that couples use more interactive communication, i.e., they prefer to use the mobile phone, telephone, video calls and videoconferences (Barbudo et al., 2014). However, in the same study, delayed forms of communication (e.g., letters, emails, mail order) have interpretative relevance, even though they have been reported by a few couples. This means that although they use interactive communication more often, the one that gives them more pleasure and satisfaction is the delayed communication (Barbudo et al., 2014). The results of the study by Carter et al. (2011) go in the same direction, indicating that these sources provide concrete and tangible materials that can be reviewed several times by the military, offering repeated support. Other studies with military spouses revealed feelings of lack of support during missions, specifically, the absence of military services with which they felt they could not count on (Carreiras, 2015; Martins et al., 2014), lack of awareness of their existence (Manigart et al., 2015), or even be considered as secondary resources (Martins et al., 2014). However, and in order for the military to feel good during the mission, military services will have to support their family by enhancing "communication" between the military and his family members (Gottman, Gottman, \& Atkins, 2011) and provide necessary support resources (Marek \& D'Aniello, 2014). Despite these concerns, studies with Portuguese military families further highlight the impact of missions on marital and parental contexts (Barbudo et al., 2014; Bóia et al., 2018; Martins et al., 2014), neglecting the extended family relationships and the communication between the deployed military and other elements of the family system, such as parents and siblings. It means that the military institution provides resources to the military, and their nuclear family, but not to the extended family, which often also cares for the military's dependents (Cozza, Chun, \& Polo, 2005).

Military parents have to deal with anxiety, concerning the welfare of their military child, while seeking to help their grandchildren cope with the worry about the safety of their parent in mission (Cozza et al., 2005) and with their new routines, especially during the deployment (Arana-Barradas, 2004). These discomfort catalysts can be aggravated if primary care of grandchildren is also performed by the grandparents (Pittman, Kerpelman, \& McFadyen, 2004). At the same time, the siblings also experience great anxiety due to the deployment of the military family member (Rodriguez \& Margolin, 2011). While conflict and rivalry characterize diverse sibling relationships, ties often become more positive and less 
conflicting during the mission period. Siblings with closer relationships tend to be more dissatisfied with physical separation, and siblings with more conflicting relationships report improvements in the relationship, as a result of distance (Rodriguez \& Margolin, 2011). Given the scarcity of studies involving deployed military parents and siblings and recognizing their role of social support to the military and to the nuclear family, it is essential to understand the emotional impact of a mission on these family members, identifying possible changes in routines and family functioning. Although military parents play a central role in the family system dynamics, they tend to be overlooked in the research on military families (Basinger \& Knobloch, 2017), as well as military siblings (Rodriguez \& Margolin, 2011).

The purposes of this study were: (1) to identify the levels of positive and/or negative affect of parents and siblings of the military, upon notification of the mission; (2) to explore the occurrence of social support and changes in family routines and dynamics during the mission; (3) to explore the impact of communication with the military on parents and siblings during deployment and the most used communication media; and (4) to identify the advice that parents and siblings would like to pass on to families of other service members.

\section{Method}

\section{Participants}

This investigation was carried out using a convenience sample, taking into account the specificity of the studied population. The sample of this study consists of 227 relatives of 92 Portuguese military service members, of which 114 are siblings $(56.1 \%$ male) and 113 are military parents $(51.4 \%$ female). The siblings of the military service members are between 14 and 57 years old $(M=29.14$, $S D=9.81)$, most of them single $(72.8 \%)$. Military parents are between 32 and 80 years old $(M=55.06, S D=9.12)$, being most of them married (77\%). Most siblings and parents lived in the northern region of Portugal $(81.6 \%$ and $75.2 \%$, respectively), with 130 participants (45.6\% of siblings and $69 \%$ of parents) residing with the military by the time of the mission. Only 37 siblings (32.4\%) had nephews and 26 parents $(23 \%)$ had grandchildren at the time of the study. Most participants fall into the low socioeconomic level (62.3\% of siblings and $80.5 \%$ of parents). In this study, participants referred to the last mission in which the military officer participated, which took place in seven separate locations, such as Kosovo $(n=145)$, Lithuania $(n=42)$, Afghanistan $(n=19)$, Timor $(n=5)$, Uganda $(n=2)$, Somalia $(n=2)$ and Bosnia $(n=1)$. The military belong essentially to the Army $(n=183)$, but also to the Navy $(n=3)$ and the Republican National Guard $(n=1)$ and have different military categories: Soldier $(n=140)$, Sergeant $(n=46)$ and Official $(n=27)$.

\section{Instruments}

Questionnaire about family members' experiences in international missions. This questionnaire, built in the context of the doctorate of one of the authors of this study, consisted of questions about participants' sociodemographic data (e.g., kinship, gender, age, occupation and area of residence), as well as information associated with military life (e.g., military category and OT of the last mission). It contained open and closed questions regarding family functioning and social support in the three phases of the mission (e.g., "There are often changes in family routines and shifts in responsibilities, such as picking up grandchild(ren) at school or paying one's child's accounts. In your case, did those changes exist? If your answer was "Yes", which ones?"). During the deployment phase, communication with the military was questioned in several aspects: means of communication used and perception of its importance (e.g., "What means of communication did you use with your child during the mission?", "Do you consider that communicating with your child during the deployment is...") and its impact (e.g., "Does communicating with your child during the mission strengthens relational bonds?"). Regarding this phase, specific questions were also asked about the possible approach of the participant to the military spouse/ boyfriend/girlfriend and the nephews/nieces/grandchildren, if any (e.g., In relation to the grandson, while your son was on mission, was there a closer approach?"). Finally, participants were asked to complete sentences with advice they would like to pass on to relatives of other military personnel (e.g., "I would like to tell the parents of the military on mission that...").

Positive and Negative Affect Schedule (PANAS). PANAS (Watson, Clark, \& Tellegen, 1988, Portuguese version of Galinha \& Pais-Ribeiro, 2005) assesses positive and negative affect in a brief and easy to administer manner. It consists of 10 items that correspond to positive affects (e.g., interested, enthusiastic) and 10 items that correspond to negative affects (e.g., disturbed, frightened), answered on a Likert scale from 1 (Nothing or very slightly) to 5 (Extremely). PANAS was answered by participants regarding the moment when the military informed them about the notification for a mission. The levels of internal consistency in this study (tested for the total sample) were adequate and identical to those found in the psychometric study of the Portuguese version (Galinha \& Pais-Ribeiro, 2005), both on the positive affect scale $(\alpha=.92$ in this study and $\alpha=.88$ in the Portuguese version) as in the negative affect scale $(\alpha=.88$ in this study and $\alpha=.87$ in the Portuguese version).

\section{Procedure}

Data collection. After the authorization of the Chief of Army Staff, the siblings and the parents of the military service members were requested to participate anonymously in this 
study. After the informed consent was read and initialed, the participants responded to the investigation protocols provided to the military family members, who returned the responses in sealed envelopes to the principal investigator, according to the stipulated deadlines. To clarify any doubts when filling out the protocol, the contact with a researcher was also provided.

Data analysis. With regard to data analysis, we carried out a descriptive statistical analysis and to perform comparisons of means ( $t$-test for independent samples) we used the SPSS Statistics 22 software. The open responses to the questionnaire were analyzed through an abductive process (Zittoun, 2017) of thematic analysis (Braun \& Clarke, 2006), using the QSR Nvivo 11 software for Mac. Participants' responses to their experiences during the mission phases were analyzed and compared with each other; common experiences were inductively described, creating thematic categories and subcategories. Simultaneously, the results described were compared with the literature, deductively examining the relationship between them and the theory, facilitating the creation of the final system of categories to meet the investigation objectives.

\section{Ethical Considerations}

This research project received a favorable opinion from the Ethics Committee of the School of Psychology of University of Lisbon, on 03/20/2014, and no protocol number was registered, only dated.

\section{Results}

We present below the results of the quantitative analyses carried out with PANAS and the closed questions of the Questionnaire on military family members' experiences in international missions. We also present the qualitative analysis of the open responses of the same questionnaire, subject to thematic analysis, and citations of the participants are presented to better convey the experiences, ensuring the confidentiality of the data (the identification of the participant refers the degree of kinship, age and OT of the last mission of the military relative). From the thematic analysis we established 61 interrelated categories organized in a hierarchical system with six main categories: (1) mission phases, (2) original family element, (3) emotional responses, (4) routine change and family communication, (5) social support provided and (6) advice to other military family members.

\section{Positive and Negative Affection upon Mission Notification}

When comparing the meanvalues of positiveand negative affect (PANAS questionnaire), siblings reported slightly higher values of positive affect compared to their parents $(M=28.31, S D=9.10 ; M=26.21, S D=9.85$, respectively; $p=.097)$ and lower values of negative affect $(M=18.17$,
$S D=7.69$ and $M=20.17, S D=7.71$, respectively; $p=.051)$, although the differences were not statistically significant.

\section{Changes in the Daily Life and Social Support Network during the Mission}

Based on the responses of the Questionnaire on military family members' experiences in times of international missions, pre-deployment, 12 siblings $(10.5 \%)$ and 9 parents $(8 \%)$ mentioned having felt changes in routines and daily life. Of these, the siblings highlighted the subcategory "readjustment of schedules", which refers mainly to the help of parents in household chores. Among the parents, the subcategory "difficulty in paying bills" stood out (4 references), since it was the military son who performed these tasks and who, during the predeployment, was in operational training. Also noted was the "physical absence of the military family member" (3 references) and his/her constant support: "Helping my parents more at home in cleaning and cooking" (brother, 14, Kosovo); "Payment of bills and household chores" (father, 52, Kosovo); "my son now has less time to be with the family" (father, 46, Lithuania).

Regarding the social support provided to the military family or the military, the siblings emphasized above all the "functional support", while the parents emphasized both the "functional support" and the "emotional support". References of functional support to siblings and parents referred to support in children's activities, household chores, and caring for the military's personal affairs: "dealing with personal matters, going to pick up children in school" (brother, 20, Lithuania). The reference of the emotional support by the parents was related to the support they give to the military themselves: "being my son living in the Azores and I here, I supported him during that time on the weekends when he came home" (mother, 65, Kosovo).

During the deployment, $80.7 \%$ of the siblings and $46.9 \%$ of the parents reported having felt changes in their routines and daily life, highlighting the "physical absence of the military" (48 siblings and 41 parents): "missing him and not having him close by for our conversations and jokes "(sister, 19, Kosovo); "lack of his presence and the help he gives me in daily tasks, organizing papers, finances, banks, etc." (mother, 70, Afghanistan). As for the changes in social support provided, only two siblings and one parent reported changes in the "functional support" given by the military, especially the support in household chores and child support: "I missed her housework a lot" (brother, 21, Kosovo); "I felt that my grandson missed his father very much" (mother, 64, Kosovo).

Many participants (28.1\% siblings and $40.7 \%$ parents) indicated that they approached the military spouse/girlfriend during the deployment phase, especially through increased conversations about the deployed military. As noted earlier, during the same phase, only 37 siblings (32.4\%) had nephews and 26 parents $(23 \%)$ had grandchildren. However, of these, less than half (12 siblings and 10 parents) reported having 
approached these younger members of the family, and this also happened essentially through more conversations about the military in mission. Regarding post-displacement, 50 siblings $(43.86 \%)$ and 39 parents $(34.51 \%)$ felt changes in their routines and daily activities, especially in terms of "readjustment of time" and "time spent together". referring to the increased presence of the military in family life, as illustrated in the following quotes: "Not having to pay so much attention to schedules and changing routines to talk to her" (Brother, 21, Kosovo); "we meet and talk more often" (sister, 43, Kosovo); "longer and livelier lunches and dinners." (father, 58, Lithuania); "at an early stage we were even longer together and then it was getting back to normal, just as it was before he went on a mission" (mother, 65, Kosovo).

As for the changes in the social support provided, among all participants in the study, only two references from siblings about "functional support" alluding to the support in domestic tasks emerged, which required some readjustment in them. Table 1 presents the frequencies related to the support felt by the siblings and parents of the military in mission, during its three phases. In all phases, the main sources of support were family members and friends of the participants. Only $2.7 \%$ of parents reported support from the military services and only in the pre-deployment phase.

Table 1

Perception of Support and Respective Sources at Different Mission Phases $(N=227)$

\begin{tabular}{lcccccc}
\hline & \multicolumn{3}{c}{ Siblings $(n=114) n(\%)$} & \multicolumn{3}{c}{ Parents $(n=113) n(\%)$} \\
\cline { 2 - 6 } Support felt & Pre-depl. & Dep. & Post-dep. & Pre-depl. & Dep. & Post-dep. \\
\cline { 2 - 6 } & $85(74.6)$ & $91(79.8)$ & $79(69.3)$ & $92(81.4)$ & $90(79.6)$ & $85(75.2)$ \\
\hline Family Members & $72(63.2)$ & $70(61.4)$ & $64(56.1)$ & $80(70.8)$ & $76(67.3)$ & $70(61.9)$ \\
Friends & $43(37.7)$ & $49(43)$ & $42(36.8)$ & $46(40.7)$ & $47(41.6)$ & $39(34.5)$ \\
Co-workers & $10(8.8)$ & $11(9.6)$ & $9(7.9)$ & $14(12.4)$ & $13(11.5)$ & $11(9.7)$ \\
Military Services & $0(0)$ & $0(0)$ & $0(0)$ & $3(2.7)$ & $0(0)$ & $0(0)$ \\
\hline
\end{tabular}

Note. Pre-depl. $=$ pre-deployment phase; Dep. $=$ deployment phase; Post-dep. $=$ post-deployment phase.

As for the emotional responses reported in the predisplacement, only one participant (sister) mentioned sadness - "I lost my ride to school, psychologically shaken and helpless" (sister, 29, Bosnia) - and this was mainly associated with the lack of support by the deployed military. In this phase, no parent reported positive or negative emotional responses. During the deployment, parents reported more negative emotional responses, highlighting "longing", "worrying" and "sadness" (35, 12 and 11 references, respectively), as evidenced in the following quotes: "Much longing, as the one who is very afraid of not embracing my dear one again "(mother, 65, Kosovo); "I felt sad" (mother, 55, Kosovo). As far as the siblings were concerned, they referred only to "longing" (20 references) as a negative emotional response "I missed him, our meetings to talk and the weekends when we had some coffee together" [brother, 31, Kosovo]) - and three positive emotional responses were pointed out by two brothers - "pride", "satisfaction" and "joy" - "longing, but at the same time, the great pride I felt for her. She is undoubtedly the best" (brother, 29, Lithuania); "he is cheerful and conveys that" (brother, 29, Lithuania). The parents, however, did not report any positive emotional responses. It was in relation to the post-deployment phase that the siblings indicated more positive emotional responses, such as "satisfaction" and "comfort" (4 and 3 references, respectively) - "felt more comfort through his company and family warmth" (sister, 21 , Kosovo) - and parents pointed more to "joy", "satisfaction" and "comfort" (7, 6 and 4 references, respectively): "Greater joy and excitement... worries were put aside" (father, 67,
Kosovo); "greater normality and a sense of security" (father, 53, Lithuania).

\section{Communication with the Military during the Mission}

The answers to the questions on communication, from the Questionnaire on military family members' experiences during international missions, also showed that the majority of participants indicated essentially positive aspects of communication during the deployment, namely the strengthening of morale $(90.4 \%$ of siblings and $93.8 \%$ of parents), improved welfare $(79.8 \%$ of siblings and $87.6 \%$ of parents), strengthening of relational bonds $(74.6 \%$ of siblings and $81.4 \%$ of parents) and easy rejoining ( $66.7 \%$ of siblings and $74.3 \%$ of parents). However, some report that anxiety (28.9\% of siblings and $42.5 \%$ of parents) increases sadness and isolation ( $7 \%$ of siblings and $17.7 \%$ of parents). The main means used by the two groups of participants in communication with the military were social networks $(66.7 \%$ of siblings and $53.1 \%$ of parents) and webcam (65.8\% of siblings and $55.8 \%$ of parents). The third means of communication most used by siblings was the e-mail $(25.4 \%)$ and by the parents was the telephone (11.5\%).

\section{Advice to other Military Family Members}

In the last part of the above mentioned questionnaire, participants pointed out some important advice to pass on 
to family members of other mission-appointed military personnel. For the siblings, the "positive attitude" subcategory $(44.12 \%$ of references) stood out from the 20 subcategories found - "everything will be OK and be proud" (brother, 50, Kosovo)-, followed by the "emotional support "( $29.41 \%$ of references) - "support them $100 \%$, even if you disagree, for them to know they have family support is essential" (brother, 40, Afghanistan). For parents, the subcategories "positive attitude" (38.04\%), "courage" (14.13\%) and "perception of the passage of time" (13.04\%) were the most mentioned, and we should note the subcategories "hope", " faith "and" pride "( $10.87 \%$ of references each $)$ - "be strong and have faith, believe it will be all right" (mother, 49, Lithuania); "Have courage and encourage your children" (mother, 58, Kosovo); "that time goes by fast and keep calm so it all goes well" (mother, 60, Somalia); "be calm and hopeful" (mother, 60, Kosovo); "it's hard to be without them, but we are proud" (father, 58, Lithuania).

\section{Discussion}

This study aimed to understand the emotional impact on the parents and siblings of the Portuguese military in mission, also identifying changes in the routines, family functioning, communication between the family and the military service members, as well as knowing advice they could give to other family members who will have similar experiences. The literature available states that separation due to mission is a major stressor for military families. (Basinger \& Knobloch, 2017; Pittman et al., 2004; Sullivan, 2015), and it is essential to understand the views of military parents and siblings, since previous studies focus mainly on spouses and children. Thus, this mixed study is pioneering in integrating parents and siblings of the military personnel.

The notification of participation in an international mission is a time when many experience fear, despair, protest and expectation of loss, accompanied by denial and emotional numbness (Van Breda, 2001), which may explain slightly higher levels of negative affection reported by parents anticipating the departure of their children to "war", compared to the siblings of the military service members. Positive affection, most reported by siblings, may be the result of a denial or the existence of some emotional numbness also typical in this phase (Van Breda, 2001). However, as Rodriguez e Margolin (2011) point out, parents experience such great suffering due to the mission that can be spread to the siblings of the military, being enhanced by the changes in the daily life and in the functional and emotional support, as our results reveal.

In the pre-deployment, the main changes felt by the siblings of the military concern the readjustment of schedules, while the parents mainly report difficulties in paying bills (since were the military who usually performed this function) and associated with the absence of the military, who is more "absorbed" by mission preparations and operational training (Pincus et al., 2001). These results also reflect family fears and challenges associated with the absence of the military, such as financial "disorganization" and changes in family roles (Allen, Rhoades, Stanley, \& Markman, 2011). During the deployment, siblings and parents report the physical absence of the military as the main change in family routine and functioning, according to the literature, since the family has to take on new tasks and routines (Pincus et al., 2001). The changes reported by both groups in the post-deployment are mainly related to the increase of time spent together and readjustment of schedules. Indeed, several adjustments to the nuclear family must be made upon the return of the military, which may also involve the extended family (Bóia et al., 2018).

In the context of the perception of social support, during the mission the main sources of support are the family members (especially the closest ones), friends and co-workers, so it is essential to stimulate the demand for this support (Pincus et al., 2001). This means that in addition to formal institutional support, the semi-formal or informal social support networks are indispensable (Kawano \& Atsuko, 2015). It should be noted that only three parents reported support from the military services and only in pre-deployment, although the Portuguese Army offered psychosocial support to immediate family members during the mission. This is probably due to the lack of dissemination of this support to the family or to the family not feeling that this support is efficient and necessary (Martins et al., 2014). Regarding changes in the social support, only parents reported changes in emotional support in the pre-deployment. However, both groups of participants report changes in functional support throughout the mission (except for parents during post-deployment), which may be explained by the need for family members to seek reciprocal support within the family, but also to seek outside help (Whealin \& Pivar, 2019), for example in housework or childcare.

Communication between the military and his family during the deployment is done by most participants through social networks (e.g., Facebook, Twitter) and webcam, showing a clear preference for interactive communication over the retarded one, although the latter is considered as one that gives more pleasure and satisfaction through written materials or testimonies (Barbudo et al., 2014). The results also reaffirm the evolution, variation and increase in access to new information and communication technologies by family members and the military, allowing a greater approximation and sharing of everyday life (Barbudo et al., 2014). This communication during the deployment is seen as very positive by most participants, since they associate it with the strengthening of relational and moral ties, improving well-being and facilitating the reunion after the mission. Thus, communication may influence the continued involvement of the military in family relationships and routines, while serving to "quench" 
longings, which was considered the most present emotion during the deployment. These results are consistent with other studies conducted with military spouses, which point to the maintenance of family relationships and of communication as fundamental for family (re)adjustment, where there is ambivalence of feelings about participating in a mission (Barbudo et al., 2014; Bóia et al., 2018; Rea et al., 2015, Van Breda, 2001).

Concerning changes at the pre-deployment emotional level, the absence of positive pre-deployment emotional responses by participants may be explained by the possible sadness, anxiety, conflict, or feelings of despair caused by the approaching separation (Van Breda, 2001). During the deployment, the most frequent emotional response is the longing for all participants, besides the concern and sadness reported by the parents, being consistent with the literature, since it is common to feel great anguish and anxiety during this phase (Rodriguez \& Margolin, 2011). However, differences were found regarding positive emotional responses, since only siblings report them (e.g., pride, satisfaction and joy). These results may be explained by the emotional stabilization along the deployment and after the initial emotional disorganization (Pincus et al., 2001; Van Breda, 2001). In the post-deployment, the concern is the negative emotional response most reported by parents and siblings, due to the attitude of the military after the mission, fitting the existing literature, since it is a very complex phase emotionally, when the military, for example, may feel excluded from family life, having difficulties readjusting to the "new" context (Barbudo et al., 2014). Regarding positive emotions, in this phase the satisfaction and comfort of siblings and parents are present, as well as their joy, which is consistent with existing studies (e.g., Van Breda, 2001). Regarding the alterations in the communication with the military spouse/ boyfriend, during the deployment there seems to be a closer approximation of the parents than of the siblings, but both refer that the approximation was mainly through the increase of conversations about the deployed military. According to some studies (Bóia et al., 2018), it was found that family members are very important in supporting the spouse of the military, which may explain this approach of parents. Regarding communication with the military's son(s), our study revealed a closer relationship with the siblings than with the parents, especially materialized in conversations about the military. Other studies indicate that parents have to help their grandchildren cope with anxiety about their father's unsafe mission (Cozza et al., 2005 ) and assist in the new routines associated with the military's deployment to the OT (Arana-Barradas, 2004). Our results show that this phenomenon happens to the military siblings who offer support to their nephews. The existence of positive and negative affection on the part of the participants when the mission is notified can be explained by the ambivalence of feelings about the military participation in an international mission, as shown by some studies (Van Breda, 2001) and their own advice, revealed in the questionnaires. In fact, these advice that both siblings and parents would like to pass on to families of other military personnel nominated for international missions were essentially focused on a "positive attitude" towards the military and the mission, marked by concepts such as courage, hope and pride. These results are consistent with the literature, since the more positive the family's feelings about the army (Allen et al., 2011; Basinger \& Knobloch, 2017), the less stress is perceived by the military and the family (Allen et al., 2011). The siblings also stress the importance of providing emotional support to the military during the deployment phase. As the Institute of Medicine (2013) points out, like parents, siblings are important sources of support for the military personnel. On the other hand, parents also find it very important to tell other family members to have courage, hope, faith and pride, as noted by Wexler and McGrath (1991), and that deployment time "goes by fast". This is how our study participants try to convey hope to relatives of other military personnel, consistent with the results found with military wives, who also demonstrated resilience and hope despite all mission demands (Walsh, 2012). Thus, it is essential for the family to have various adaptive resources and coping strategies to deal with new discomfort-inducing situations derived from the mission (Tomforde, 2015).

This study presents some limitations to bear in mind, namely the heterogeneity of the sample, which may have led to responses with different emotional content and perspectives (e.g., large differences in sibling ages), and the fact that the response to PANAS was only for the notification. On the other hand, the questionnaire about family members' experiences in international missions was recently built for a specific investigation in which this study fits, being still an experimental version and not generalizable. This study also does not contemplate the total independence of the collected data, since there are participants from the same household (parents and siblings of the same military in mission). Considering that this is the first study carried out with parents and brothers of Portuguese military, future investigations should seek to deepen some of the results found. Thus, it would be pertinent to understand if there are differences in the level of affections and emotional responses, if the military is deployed in a peace or war OT, also paying attention to the perceived danger level of the mission, and if these differences may also be verified in relation to age, sex and rank (category) of the military. It would be equally important to develop longitudinal studies with this population and including all elements of military families (nuclear and extended), allowing the understanding of different experiences and their mutual influence during the mission.

Some practical implications can be considered based on this study, which revealed a need for preventive intervention early in the pre-deployment phase, for example through group interventions for family members after mission notification, with the aim of reducing the negative affection verified at that moment. In this way, the 
sharing of experiences can be stimulated, as some family members may have already experienced similar previous moments, being sources of learning for the remaining participants. These therapeutic encounters could also be useful during the deployment phase, aimed at sharing experiences and coping strategies used to overcome major changes in their routines and family dynamics, focusing the attention on the positive aspects of the mission, increasing positive emotional responses during this phase. During the mission, it would also be helpful to develop social and organizational support resources for military family members, making it easier for them to adapt to changes in the family system. We should also stress the need to prevent the evolution of psychological illnesses of siblings and parents of the military (e.g., depression). The existence of a family support nucleus in the military readiness units could be a resource that allowed the perception of direct support from the military services by parents and siblings, as well as from other elements of the family system, thus complementing the psychosocial military support services. already existing, often unknown by military families. This ignorance may exist because, while spouses and children of the military may have the closest support, as they may live in or near military units, the siblings and parents of the military may be more distant and may not know how to access the existing psychosocial support. It will be crucial that technicians (e.g., military psychologists and sociologists) provide psychoeducation, prevention and intervention programs for the extended family of the deployed military personnel. Despite the increasing attention from investigators on the impact of the mission on spouses and children of deployed military personnel, this groundbreaking study highlighted that it is very important to support widely ignored elements of the family system, such as military parents and siblings, since they are often the functional and emotional support of the military's nuclear family and of the military himself or herself. Thus, this study sought to contribute to the knowledge of the impact of an international military mission on the parents and siblings of the military in mission, indicating the changes in daily life, the emotions and the most relevant sources of support during this period, because when a military family member is appointed and deployed to an international mission, this fact may cause "cascade" effects throughout the family system.

\section{References}

Allen, E. S., Rhoades, G. K., Stanley, S. M., \& Markman, H. J. (2011). On the home front: Stress for recently deployed army couples. Family Process, 50(2), 235-247. doi:10.1111/j.1545-5300.2011.01357.x

Arana-Barradas, L.A. (2004). The children left behind. Airmen, 48(11), 36-41.
Barbudo, M., Francisco, R., \& Santos, R. (2014). Vivências de militares em missões internacionais: $O$ impacto nas relações conjugais [Service members experiences in international missions: The impact on conjugal relationships]. Revista de Psicologia Militar, 23(1), 9-35.

Basinger, E. D., \& Knobloch, L. K. (2017). A grounded theory of online coping by parents of military service members. Journal of Social and Personal Relationships, 35(5), 1-20. doi:10.1177/0265407517694769

Bóia, A., Marques, T., Francisco, R., Ribeiro, M. T., \& Santos, R. P. (2018). International missions, marital relationships and parenting in military families: An exploratory study. Journal of Child and Family Studies, 27(1), 302-315. doi:10.1007/s10826-017-0873-7

Braun, V. \& Clarke, V. (2006). Using thematic analysis in psychology. Qualitative Research in Psychology, 3, 77-101. doi:10.1191/1478088706qp063oa

Bunch, S. G., Eastman, B. J., \& Moore, R. R. (2007). A profile of grandparents raising grandchildren as a result of parental military deployment. Journal of Human Behavior in the Social Environment, 15(4), 1-12. doi:10.1300/J137v15n04

Carreiras, H. (2015). The invisible families of Portuguese soldiers: From colonial wars to contemporary missions. In R. Moelker, M. Andres, G. Bowen, \& P. Manigart (Eds.), Military families and war in the 21st century (pp. 261-277). London: Routledge. doi:10.4324/9780203407530

Carter, S., Loew, B., Allen, E., Stanley, S., Rhoades, G., \& Markman, H. (2011). Relationships between soldiers' PTSD symptoms and spousal communication during deployment. Journal of Traumatic Stress, 24(3), 352-355. doi:10.1002/jts.20649

Carter, S. P., \& Renshaw, K. D. (2016). Spousal communication during military deployments: A review. Journal of Family Issues, 37(16), 2309-2332. doi:10.1177/0192513X14567956

Cozza, S. J., Chun, R. S., \& Polo, J. A. (2005). Military families and children during operation Iraqi freedom. Psychiatric Quarterly, 76(4), 371-378. doi:10.1007/ s11126-005-4973-y

Daly, K. J. (2007). Qualitative methods for family studies \& human development. Thousand Oaks, CA: Sage. doi: $10.4135 / 9781452224800$

Galinha, I. C., \& Pais-Ribeiro, J. L. (2005). Contribuição para o estudo da versão portuguesa da Positive and Negative Affect Schedule (PANAS): II - Estudo psicométrico [Contribution to the study of the Portuguese version of the Positive and Negative Affect Schedule (PANAS): II - Psychometric study]. Análise Psicológica, 23(2), 219-227. doi:10.14417/ap.84 
Gottman, J. M., Gottman, J. S., \& Atkins, C. L. (2011). The comprehensive soldier fitness program: Family skills component. American Psychologist, 66(1), 52-57. doi:10.1037/a0021706

Greene, T., Buckman, J., Dandeker, C., \& Greenberg, N. (2010). How communication with families can both help and hinder service members' mental health and occupational effectiveness on deployment. Military Medicine, 175(10), 745-749. doi:10.7205/ MILMED-D-09-00278

Houston, J. B., Pfefferbaum, B., Sherman, M. D., Melson, A. G., \& Brand, M. W. (2013). Family communication across the military deployment experience: Child and spouse report of communication frequency and quality and associated emotions, behaviors, and reactions. Journal of Loss and Trauma, 18, 103-119. doi:10.1080/1 5325024.2012.684576

Institute of Medicine (2013). Returning home from Iraq and Afghanistan: Assessment of readjustment needs of veterans, service members, and their families. Washington, DC: The National Academies Press. doi:10.17226/13499

Kawano, H., \& Atsuko, F. (2015). Family support and the Japan Self-Defense Forces: Challenges and developing new programs. In R. Moelker, M. Andres, G. Bowen, \& P. Manigart (Eds.), Military families and war in the 21st century: Comparative perspectives (pp. 302-318). Abingdon, United Kingdom: Routledge. doi:10.4324/9780203407530

Manigart, P., Lecoq, V., \& Bue S. L. (2015). How do military families cope with multiple deployments abroad of loved ones? The case of Belgium. In R. Moelker, M. Andres, G. Bowen, \& P. Manigart (Eds.), Military families and war in the 21st century: Comparative perspectives (pp. 242-260). Abingdon, United Kingdom: Routledge. doi:10.4324/9780203407530

Marek, L. I. \& D'Aniello, C. (2014). Reintegration stress and family mental health: Implications for therapists working with reintegrating military families. Contemporary Family Therapy, 36, 443-451. doi:10.1007/s10591-0149316-4

Martins, T., Santos, R., \& Francisco, R. (2014). Mudanças familiares e rede social dos cônjuges de militares em missão: Um estudo exploratório [Family changes and social network of spouses of military personnel on mission: An exploratory study]. Revista de Psicologia Militar, 23, 131-155.

Matthews-Juarez, p., Juarez, P., \& Faulkner, R. (2013). Social media and military families: A perspective. Journal of Human Behavior in the Social Environment, 23, 769776. doi:10.1080/10911359.2013.795073
Pincus, S. H., House, R., Christenson, J., \& Alder, L. E. (2001). The emotional cycle of deployment: A military family perspective. US Army Medical Department Journal, 4(5), 6.

Pittman, J. F., Kerpelman, J. L., \& McFadyen, J. M. (2004). Internal and external adaptation in army families: Lessons from operations desert shield and desert storm. Family Relations, 53(3), 249-260. doi:10.1111/j.01976664.2004.0001.x

Rea, J., Behnke, A., Huff, N., \& Allen, K. (2015). The role of online communication in the lives of military spouses. Contemporary Family Therapy, 37(3), 329-339. doi:10.1007/s10591-015-9346-6

Rodriguez, A. J., \& Margolin, G. (2011). Siblings of military servicemembers: A qualitative exploration of individual and family systems reactions. Professional Psychology, Research and Practice, 42, 316-323. doi:10.1037/ a0024527

Solomon, D. H., \& Vangelisti, A. L. (2014). Relationship development. In P. J. Schultz, P. Cobley (Series Eds.), \& C. R. Berger (Vol. Ed.), Handbooks of communication science: Vol. 6. Interpersonal communication (pp. 347369). Berlin, Germany: De Gruyter Mouton.

Sullivan, K. (2005). An application of family stress theory to clinical work with military families and other vulnerable populations. Clinical Social Work Journal, 43, 89-97. doi:10.1007/s10615-014-0500-7

Tomforde, M. (2015). The emotional cycle of deployment. In R. Moelker, M. Andres, G. Bowen, \& P. Manigart (Eds.), Military families and war in the 21st century: Comparative perspectives (pp. 87-106). Abingdon, United Kingdom: Routledge. doi:10.4324/9780203407530

Van Breda, A. D. (2001). Resilience theory: A literature review: With special chapters on deployment resilience in military families \& resilience theory in social work. Pretoria, South Africa: Military Health Service/Military Psychological Institute/Social Work Research \& Development.

Walsh, F. (2012). Family resilience: Strengths forged through adversity. In F. Walsh (Ed.), Normal family processes (pp. 399-427). New York, NY: Guilford.

Wexler, H. K. \& McGrath, E. (1991). Family member stress reactions to military involvement separation. Psychotherapy: Theory, Research, Practice, Training, 28(3), 515-519.

Whealin, J., \& Pivar, I. (2019). Coping when a family member has been called to war. Taken from https://www. achievesolutions.net/achievesolutions/en/att/10868. genpdf 
Zittoun, T. (2017). Modalities of generalization through single case studies. Integrative Psychological and Behavioural Science, 51(2), 171-194. doi:10.1007/ s12124-016-9367-1

Ana Santos Duarte holds a Master's Degree from the Universidade de Lisboa, Lisboa-Portugal.

Rita Francisco is a Professor of the Universidade Católica Portuguesa, Lisboa-Portugal.

Maria Teresa Ribeiro is a Professor of the Universidade de Lisboa, Lisboa-Portugal.

Renato Pessoa dos Santos is a Ph.D candidate of the Universidade de Lisboa, Lisboa-Portugal.

Authors' Contribution:

All authors made substantial contributions to the conception and design of this study, to the data analysis and interpretation, and to the manuscript revision and approval of the final version. All authors assume public responsibility for the content of the manuscript.

Received: Mar. 23, 2018

1st Revision: Sep. 25, 2018

2nd Revision: Dec. 10, 2018

Approved: Dec. 27, 2018

How to cite this article:

Duarte, A. S., Francisco, R., Ribeiro, M. T., \& Santos, R. P.(2020). Daily life, communication and affections of siblings and parents of military service members in mission. Paidéia (Ribeirão Preto), 30, e3002. doi:http://dx.doi.org/10.1590/1982-4327e3002 